\title{
KONTRIBUSI MANAJEMEN HUMAS \\ DALAM MENINGKATKAN KEPERCAYAAN WALI SISWA KEPADA SDIT BIAS GIWANGAN YOGYAKARTA
}

Siti Aminatun, Ahyar

STAI Terpadu Yogyakarta

\begin{abstract}
Abstrak: Penelitian ini bertujuan untuk mengetahui seberapa efektif peranan humas SDIT BIAS Giwangan Yogyakarta dalam rangka meningkatkan kepercayaan wali siswa kepada sekolah. Jenis penelitian yang digunakan dalam penelitian ini adalah penelitian deskriptif kualitatif. Untuk menjamin keabsahan data penelitian ini menggunakan teknik triangulasi sumber, teknik dan waktu.
\end{abstract}

Kata Kunci: Manajemen Humas, Kepercayaan

\section{Pendahuluan}

Seperti yang kita ketahui pendidikan merupakan hal yang sangat penting. Terutama di era globalisasi seperti sekarang ini, dimana persaingan semakin meningkat dan perkembangan teknologi yang semakin pesat mengharuskan terlahirnya generasi penerus bangsa yang mampu berfikir kritis dan yang lebih pintar sesuai dengan perubahan yang terjadi. Dan lembaga pendidikan baik formal maupun non formal dituntut untuk menjadi pengemban amanat ilmu pengetahuan untuk menjawab.

Menurut Suyanto pada masa mendatang pendidikan merupakan investasi manusia (human investment) penting yang harus dirancang dan dibiayai secara lebih memadai, agar sumber daya manusia Indonesia mampu tumbuh dan bersaing dengan bangsa lain. Dalam sebuah proses pembangunan pendidikan harus ada upaya sadar dari pemerintah, masyarakat, dan keluarga semua perlu dilakukan secara terus menerus tanpa henti, supaya para generasi mampu merespon secara proaktif terhadap perkembangan jaman. ${ }^{29}$

Pada dasarnya lembaga pendidikan merupakan organisasi sosial yang memiliki publik internal dan eksternal. Lembaga pendidikan merupakan agen perubahan dan tempat untuk menyalurkan ilmu kepada generasi penerus bangsa. Pendidikan tidak hanya merupakan kewajiban pemerintah, sekolah, dan guru saja, tapi juga merupakan tanggung jawab keluarga dan masayarakat. Masyarakat diharapkan peran sertanya dalam melaksanakan dan menyelenggarakan pendidikan, terutama dalam mendidik moral, norma, dan etika yang sesuai dengan agama dan kesepakatan masyarakat. Siswa belajar disekolah dalam waktu terbatas, sedangkan waktu terbanyak ada di rumah dan masyarakat.

${ }^{29}$ Zulkarnain Nasution, Manajemen Humas dalam Lembaga Pendidikan,(Malang: UMM Press, 2010), hal.2 
UU No. 20/ 2003 tentang Sisdiknas. Pada Bab XV Pasal 54 dinyatakan bahwa: (1) Peran serta masyarakat dalam pendidikan meliputi peran serta perseorangan, kelompok, keluarga, organisasi profesi, pengusaha, dan organisasi kemasyarakatan dalam penyelenggaraan dan pengendalian mutu layanan pendidikan. (2) Masyarakat dapat berperan serta sebagai sumber pelaksana dan pengguna hasil pendidikan. (3) ketentuan mengenai peran serta masyarakat sebagaimana dimaksud pada ayat (1) dan (2) diatur lebih lanjut dengan peraturan pemerintah. ${ }^{30}$

Masyarakat merupakan komponen utama dalam terselenggaranya proses pendidikan. Kontribusi masyarakat di lingkungan sekolah sangat perlu dioptimalkan sebagai upaya pemberdayaan dalam rangka mewujudkan visi dan misi sekolah dengan paradigma pendidikan yang baru. Masyarakat dapat memberikan sumbangsihnya kepada sekolah dengan memberikan masukan-masukan terutama dalam penyusunan program-program sekolah. Namun disamping itu, masyarakat mempunyai kontribusi dalam penentuan citra kualitas suatu lembaga. Masyarakat mempunyai kekuatan paradigma bagi suatu lembaga, baik itu paradigma negatif maupun positif.

Di era globalisasi masyarakat akan lebih selektif dan berhati-hati dalam memilih lembaga pendidikan. Maka lembaga pendidikan harus berupaya untuk menciptakan citra sebaik mungkin di hadapan masyarakat. Namun pada masa sekarang semakin marak kasus yang terjadi pada lembaga pendidikan seperti fenomena geng pelajar di berbagai daerah dan sekolah yang melakukan kekerasan kolektif. Belum lagi kekerasan yang melibatkan guru dan siswa, termasuk kasus pelecehan seksual, rokok, narkoba dan miras yang pasang surut meramaikan peredaran berita di media massa. Kasus-kasus tersebut dapat menciptakan citra yang buruk pada lembaga pendidikan.

Seperti yang kita tahu bahwa bukan hal yang mudah untuk mengembalikan image positif. Pengembalian citra menjadi tantangan penting bagi lembaga pendidikan. Dalam hal ini humas atau public relations dalam lembaga pendidikan dapat membantu dalam mengembalikan citra suatu perusahaan atau lembaga pendidikan. Disebabkan fungsi humas atau public relations diantaranya mengelola opini publik guna menumbuhkan kemauan baik, partisipasi, dan keterlibatan dari publik dalam rangka menciptakan opini publik yang baik. ${ }^{31}$

Terciptanya opini publik didasarkan saling mempercayai adanya kesadaran akan kebutuhan bersama, tugas praktisi humas mengelola opini publik agar kesan masyarakat terhadap lembaga pendidikan menjadi positif. Apabila kesan masyarakat positif terhadap lembaga pendidikan maka menciptakan kepercayaan masyarakat terutama orang tua sebagai wali siswa untuk memasukkan putra-putrinya pada lembaga pedidikan

30 UU RI No. 20 Tahun 2003 Tentang Pendidikan Nasional

31 Zulkarnain Nasution, Manajemen Humas,... hal. 17. 
tersebut. Seperti halnya di SDIT SIBI BIAS Giwangan, kepercayaan masyarakat terhadap sekolah terlihat dari siswa-siswi yang merupakan kakak beradik. Misal, siswa di kelas 2 merupakan adik dari salah satu siswa kelas 5 .

Namun sayangnya, pada masa sekarang peran humas dalam dunia pendidikan tidak difungsikan secara maksimal oleh lembaga-lembaga pendidikan. Hal ini disebabkan karena kurangnya pengetahuan yang dimiliki oleh pelaksana dan pengelola lembaga tersebut terhadap arti penting peran humas yang sesungguhnya.

Banyak yang menganggap peran humas tidak penting bagi instansi pendidikan. Terutama ini banyak di lakukan oleh sekolah-sekolah yang berada di bawah naungan pemerintah, mulai dari level SD sampai SMA. Kecuali di level universitas, sudah ada staf atau petugas sendiri untuk bagian humas atau public relations. Memang untuk lembaga pendidikan swasta atau dibawah naungan yayasan tertentu sudah mulai digunakan cara-cara kehumasan tersebut, tapi biasanya kurang maksimal. Dan walaupun ada job diskripsi untuk itu tidak bisa bekerja dengan baik serta kurang bisa membawakan peran bagaimana semestinya seorang humas itu. Padahal dalam lembaga pendidikan peran humas atau public relations sangatlah penting untuk membangun dan menjaga image yang positif, mengingat lembaga pendidikan yang memiliki publik internal dan eksternal.

Berdasarkan uraian di atas maka peneliti tertarik untuk meneliti hal yang terkait dengan manajemen humas di LPIT BIAS dengan judul "Kontribusi Manajemen Hubungan Masyarakat (HUMAS) dalam Meningkatkan Kepercayaan Wali Siswa pada SDIT BIAS Giwangan."

\section{Metode Penelitian}

Penelitian ini menggunakan jenis penelitian deskriptif yaitu penelitian yang diarahkan untuk memberikan gejala-gejala, fakta-fakta, atau kejadiankejadian secara sistematis dan akurat, mengenai sifat-sifat populasi atau daerah tertentu. ${ }^{32}$ Penelitian ini juga merupakan penelitian kualitaf yaitu penelitian yang menghasilkan data deskriptif berupa kata-kata tertulis atau lisan dari orang-orang dan perilaku yang dapat diamati. Dengan kata lain penelitian deskriptif kualitatif ini bertujuan untuk mendapatkan informasiinformasi yang jelas serta lengkap yang berhubungan dengan humas di SDIT SIBI BIAS Giwangan.

Tempat yang dipilih dalam penelitian ini adalah SDIT Bina Anak Sholeh (BIAS) Giwangan, yang beralamat di Jl. Mendung Warih No. 155 Giwangan, Yogyakrta.

32 DR. Drs. Yatim Riyanto, M.Pd, Metodologi Penelitian Pendidikan, (Surabaya: Penerbit SIC, Cetakan ke 3 2010), hal.23

26 
Waktu penelitian dilakukan mulai bulan Juni - Juli 2014 dan disesuaikan dengan jadwal akademik SDIT Bina Anak Sholeh (BIAS) Giwangan Yokyakarta.

Dalam penelitian ini menggunakan teknik purposive sampling yaitu teknik pengambilan sumber data dengan pertimbangan tertentu. ${ }^{33}$ Peneliti memilih Kepala Sekolah SDIT SIBI BIAS Giwangan sebagai sampel dalam penelitian ini, karena peneliti menganggap bahwa Kepala Sekolah adalah orang yang paling dipercaya untuk memberikan informasi yang lengkap, Pegawai bagian Humas di SDIT SIBI BIAS Giwangan karena bagian humas adalah orang yang sangat paham dan mengetahui secara menyeluruh tentang kehumasan di sekolah, Ustadzah Wali Kelas, orang tua siswa.

Sumber Data merupakan tahapan dalam proses penelitian yang penting, karena hanya dengan mendapatkan data yang tepat maka proses penelitian akan berlangsung sampai peneliti mendapatkan jawaban dari perumusan masalah yang sudah ditetapkan. Untuk menjawab rumusan masalah tersebut dibutuhkan data primer dan data skunder, diantaranya:

1. Data Primer

Data primer yaitu data-data yang diperoleh secara langsung dari sumber pertama baik individu atau perseorangan seperti hasil observasi, interview, dan studi dokumen. yang diajukan oleh peneliti terhadap kepala sekolah, guru, karyawan di SDIT SIBI BIAS Giwangan Yogyakarta. Dalam penelitian ini, data diperoleh dari berbagai responden atau informan. Adapun responden atau informan diambil dari pihak internal sekolah maupun pihak eksternal sekolah. Informan dari pihak internal sekolah antara lain Kepala Sekolah, Personalian Bagian Humas SDIT BIAS Giwangan, Ustadzah Wali Kelas, sedangkan informan dari pihak internal sekolah yaitu wali siswa dari berbagai kelas, diantaranya wali siswa kelas 1, 2, 3, dan 5. Adapun daftar informan atau responden dalam penelitian ini antara lain:

Daftar Responden Penelitian

\begin{tabular}{|c|l|l|}
\hline No & \multicolumn{1}{|c|}{ Nara Sumber } & \multicolumn{1}{c|}{ Jabatan } \\
\hline 1 & Nasoha Alasyar & $\begin{array}{l}\text { Kepala Sekolah, Personalia bagian } \\
\text { Humas SDIT BIAS Giwangan }\end{array}$ \\
\hline 2 & Kurnia Zuliyanti & Ustadzah Wali Kelas 2 \\
\hline 3 & Uswatun Khasanah & Wali Siswa Kelas 1 \\
\hline 4 & Ananda Murtiningtyas & Wali Siswa Kelas 2 \\
\hline 5 & Arif & Wali Siswa Kelas 2 \\
\hline 6 & Wiwit & Wali Siswa Kelas 3 dan 5 \\
\hline
\end{tabular}

33 Ibid. hal. 300 


\section{Data Sekunder}

Data sekunder adalah data-data yang dikumpulkan dan digunakan untuk mendukung data primer. Adapun data sekunder peneliti mengambil kepustakaan meliputi profil sekolah, papan dokumentasi sekolah, serta catatan-catatan tentang apa saja yang berhubungan dengan masalah ini khususnya yang dimiliki oleh SDIT SIBI BIAS Giwangan Yogyakarta.

Teknik pengumpulan data merupakan langkah yang paling utama dalam penelitian, karena tujuan utama dari penelitian adalah mendapatkan data. Tanpa mengetahui teknik pengumpulan data, maka peneliti tidak akan mendapatkan data yang memenuhi standar data yang ditetapkan. Oleh karena itu agar hasil yang diperoleh dalam penelitian ini benar-benar data yang akurat dan dapat dipertanggungjawabkan, maka teknik pengumpulan data yang peneliti gunakan dalam penelitian ini adalah sebagai berikut:

\section{Interview / Wawancara}

Interview atau wawancara merupakan metode pengumpulan data yang menghendaki komunikasi langsung antara penyelidik atau peneliti dengan subyek atau responden. Dalam interview biasanya terjadi tanya jawab sepihak yang dilakukan secara sistematis dan berpijak pada tujuan penelitian. ${ }^{34}$ Maksud penggunaan wawancara sebagai metode pengumpulan data adalah untuk menggali informasi tentang kejadian yang sudah lampau, sekarang, dan harapan-harapan subyek yang diinginkan. Wawancara yang dilakukan dalam penelitian ini menggunakan pedoman wawancara agar pelaksanaan wawancara berlangsung secara sistematis dan terarah. Selain itu, wawancara akan dilakukan secara mendalam terhadap nara sumber yang dianggap oleh peneliti mampu memberikan informasi secara lengkap guna hasil penenlitian.

\section{Observasi}

Observasi adalah pengamatan dan pencatatan secara sistematik terhadap gejala yang tampak pada obyek penelitian. ${ }^{35}$ Metode ini digunakan untuk memperoleh data-data yang berkaitan dengan humas. Dalam penelitian ini peneliti melakukan observasi secara langsung ke SDIT BIAS Giwangan sebagai tempat berlangsungnya semua kegiatan sekolah. Dari hasil data observasi yang nantinya akan diolah menjadi sebuah data yang sesuai dengan realiti atau nyata dalam lingkungan sekitar sekolah, dan akan dipaparkan dalam skripsi ini.

${ }^{34}$ DR. Drs. Yatim Riyanto, M.Pd, Metodologi Penelitian,... hal.82

35 S. Margono, Metodologi Penelitian Pendidikan, (Jakarta: Rineka Cipta, 2004), Cet.4, hlm.158. 


\section{Dokumentasi}

Dokumenentasi berasal dari kata Dokumen, yang artinya barang-barang tertulis. Metode dokumentasi berarti cara mengumpulkan data dengan mencatat data-data yang sudah ada. ${ }^{36}$ Metode ini digunakan untuk mendapatkan data berupa sejarah berdiri, struktur organisasi, Visi dan Misi SDIT SIBI BIAS Giwangan, serta data-data lain yang bersifat dokumen.

\section{Teknik Analisis Data}

Penulis menganalisis data dengan analisis data model Miles and Huberman selama berada di lapangan. Telah dipahami bersama dalam analisis data kualitatif dilakukan secara interaktif dan berlangsung secara terus-menerus sampai tuntas sehingga datanya sudah jenuh. Aktivits dalam analisis data meliputi reduksi data (data reduction), penyajian data (data display), dan verivication (contlution drawing) atau sering dikenal dengan penarikan kesimpulan dan verifikasi.

\section{Reduksi Data (Data Reduction)}

Data yang diperoleh dari lapangan jumlahnya cukup banyak, untuk itu maka perlu dicatat secara teliti dan rinci, untuk itu segera dibutuhkan analisis data melalui reduksi data. Mereduksi data berarti merangkum, memilih hal-hal yang pokok, memfokuskan pada hal-hal yang penting, dicari tema dan polanya dan membuang yang tidak perlu. ${ }^{37}$ Dengan begitu, maka data yang nantinya akan dipaparkan dalam penelitian ini akan lebih jelas dan mudah dipahami karena hanya merupakan datadata yang memebirikan informasi yang penting dan memebri gambaran secara lebih menyeluruh.

2. Penyajian Data (Data Display)

Setelah data direduksi, maka langkah selanjutnya adalah mendisplaykan data. Dalam penelitian ini penyajian data akan disajikan dengan uraian teks yang bersifat naratif. Tujuan dalam pendisplayan data ini adalah agar hasil penelitian ini mudah untuk dipahami.

3. Verivication (Contlution Drawing)

Langkah ketiga dalam analisis data adalah Verivication (Contlution Drawingen) atau penarikan kesimpulan dan verifikasi. Dengan langkah ini maka diharapkan dapat menjawab rumusan maslah yang telah ditetapkan sehingga menjadi suatu masalah yang sudah jelas dan mungkin dapat menemukan temuan baru yang sebelumnya belum pernah ada.

36 DR. Drs. Yatim Riyanto, M.Pd, Metodologi Penelitian,... hal.103.

37 Prof. Dr. sugiyono, Metode Pendidikan Pendekatan Kuantitaif, Kualitatif, dan RED,(Bandung: Penerbit Alfa Beta, 2013), hal. 338 


\section{Keabsahan Data}

Dalam pengujian keabsahan data, penelitian ini menggunakan teknik triangulasi. Triangulasi dalam pengujian ini diartikan sebagai pengecekan data dari berbagai sumber dengan berbagai cara, dan berbagai waktu. Dengan demikian terdapat triangulasi sumber, triangulasi teknik pengumpulan data, dan waktu. ${ }^{38}$

1. Triangulasi Sumber

Triangulasi sumber untuk menguji kredibilitas data dilakukan dengan cara mengecek data yang telah diperoleh melalui beberapa sumber. Data tersebut dideskripsikan, dikategorikan, mana pandangan yang sama, yang berbeda, dan mana spesifik dari sumber-sumber data terebut. Data yang telah dianalisis oleh peneliti sehingga menghasilkan suatu kesimpulan selanjutnya dimintakan kesepakatan (member check) dengan sumber-sumber data tersebut.

2. Triangulasi Teknik

Triangulasi teknik dilakukan dengan cara mengecek data kepada sumber yang sama dengan teknik yang berbeda. Misalnya data diperoleh dengan wawancara, lalu dicek dengan observasi, dokumentasi atau kuesioner. Bila dengan tiga teknik pengujian kredibilitas data tersebut, menghasilkan data yang berbeda-beda, maka peneliti melakukan diskusi lebih lanjut kepada sumber data yang bersangkutan atau yang lain, untuk memastikan data mana yang dianggap benar. Atau mungkin semuanya benar, karena sudut pandangnya berbeda-beda.

3. Triangulasi Waktu

Waktu juga sering mempengaruhi kredibilitas data. Data yang dikumpulkan dengan teknik wawancara di pagi hari pada saat nara sumber masih segar, belum banyak masalah, akan memberikan data yang lebih valid sehingga lebih kredibel. Untuk itu dalam rangka pengujian kredibilitas data dapat dilakukan dengan cara melakukan pengecekan dengan wawancara, observasi atau teknik lain dalam waktu atau situasi yang berbeda. Bila hasil uji menghasilkan data yang berbeda, maka dilakukan secara berulang-ulang sehinga sampai ditemukan kepastian datanya.

\section{Pembahasan}

1. Pelaksanaan Manajemen Humas di SDIT BIAS Giwangan 
Peran dan fungsi humas dalam lembaga pendidikan adalah untuk menjaga keharmonisan hubungan antara sekolah dengan masyarakat terutama orang tua siswa dan warga sekitar sekolah. Adapun aktivitas manajemen humas SDIT BIAS Giawangan antara lain:

a. Kegiatan internal

Kegiatan internal merupakan kegiatan yang ditujukan untuk publisitas ke dalam sasarannya tidak lain adalah warga sekolah yang bersangkutan, yakni para guru, tenaga tata usaha, dan seluruh siswa. Kegiatan ini juga bisa dilakukan secara langsung seperti; rapat dewan guru, upacara sekolah, rekreasi bersama, dan lain-lain. Dan yang diakukan secara tidak langsung antara lain: menyampaikan informasi melalui surat edaran, papan pengumuman di sekolah, majalah dinding dan lain-lain. ${ }^{39}$ Adapun bentuk kegiatan internal yang dilakukan di SDIT BIAS Giwangan antara lain:

1) Rapat Guru atau Meeting

Rapat guru diadakan rutin dalam setiap minggunya. Adapun jadwal rapat tertentu sesuai kebutuhan pembahasan masalah atau kegiatan yang telah terjadi maupun yang akan dilaksanakan. Adapaun serangkaian rapat dalam setiap minggunya, antara lain: ${ }^{40}$

a) Pada Hari Senin, seluruh ustadz/ah berkumpul dan mengadakan bimbingan potensi yang dimiliki setiap ustadz/ah yang ditujukan untuk mengembangkan kemampuan ustadz/ah di bidang lain selain mengajar seperti beryanyi, menari ataupun menggunakan berbagai alat musik.

b) Pada Hari Selasa, ustadz/ah mengadakan rapat penanganan anak. Rapat ini diadakan guna membahas berbagai kendala yang dihadapi di kelas, bagai mana solusinya, kekurangannya apa dan apa yang harus diperbaiki baik dari kelas satu sampai dengan kelas enam.

c) Pada Hari Jum'at, diadakan meeting ustadz/ah guna membahas agenda kegiatan yang akan dilaksanakan pada hari Sabtu dan kegiatan untuk satu minggu kedepan. Namun apabila rapat penanganan anak pada Hari Selasa belum tuntas atau masih ada yang harus dibahas, maka dilanjutkan pada Hari Jum'at ini.

2) Upacara

Upacara di SDIT BIAS Giwangan dilaksanakan seminggu sekali yaitu pada Hari Senin di halaman sekolah yang cukup luas.

${ }^{39}$ Suryosubroto, Manajemen Pendidikan di Sekolah (Jakarta: PT Asdi Mahasatya, 2004), 167-168.

${ }^{40}$ Hasil wawancara dengan Ustadzah Kurnia wali kelas 2A pada Senin, 21 Juli 2014 
Dengan upacara maka diharapkan dapat menambah rasa nasionalisme anak- anak dan ustadz/ah sekaligus menambah semangat kesatuan dan kebersamaan diantara siswa dan ustadz/ah karena upacara tersebut diikuti oleh seluruh ustadz/ah dan siswa dari kelas satu sampai kelas enam. Selain itu juga mengajarkan siswa-siswi untuk belajar kedisiplinan, jiwa kepemimpinan dan ketertiban. Biasanya upacara ini dipimpin oleh salah satu ustadz/ah. Kemudian ustadz/ah yang bertugas memimpin upacara akan menyampaikan amanatnya kepada seluruh peserta upacara, terutama siswa- siswinya. Amanat yang disampaikan biasanya merupakan pesan atau nasihat yang ditujukan kepada siswa- siswinya.

3) Rihlah

Rihlah atau rekreasi khusus untuk ustadz/ah diadakan setiap 2 tahun sekali. Adapaun tujuan dari rihlah tersebut adalah memberikan kesempatan bagi ustadz/ah serta karyawan BIAS untuk menikmati liburan, melepaskan rasa penat serta terbebas dari kesibukan kerja seperti mengajar dan kesibukan di sekolah lainya. Selain itu juga mempererat hubungan internal sesama ustadz/ah karena rihlah tersebut biasanya berlangsung hingga beberapa hari, dimana ustadz/ah dapat melewati hari bersamasama dengan rasa kebersamaan dan suasana yang berbeda dengan kebersamaan saat bekerja di sekolah.

4) Pengajian Rutin Mingguan

Dalam rangka memperkuat tali silaturahmi antar ustadz/ah, maka diadakan pengajian rurtin mingguan atau yang lebih dikenal dengan kajian. Kajian ini dilaksanakan pada Hari Rabu sore mulai jam 16.30 WIB di Gedung Kucala, Kota Baru. Kajian ini diselenggarakan oleh Yayasan Bina Anak Sholeh (BIAS) yang diikuti oleh seluruh ustadz/ah di jenjang pendidikan Yayasan Bina Anak Sholeh (BIAS) Yogyakarta. Adapun tujuan utama selain memperkuat tali silaturahmi antar ustadz/ah adalah menambah wawasan khasanah ilmu Islam seperti aqidah, fiqih, hadist, BTAQ, dll. Kajian ini dipimpin langsung oleh Direktur Yayasan Bina Anak Sholeh Yogyakarta atau uastadz/ah senior. Untuk lebih mendalami dan memahami dari materi yang disampaikan saat kajian, maka diadakan sesi small group. Biasanya kelompok small group terdiri dari 10-15 ustadz/ah dan salah satu nya merupakan ustadz/ah senior yang menjadi ketua atau pendamping. Dalam small group materi yang disampaikan diawal sesi akan dibahas ulang, dan apabila ada yang masih belum paham maka akan diperjelas pembahasannya. Sehingga diharapkan apa yang telah disampaikan dapat dipahami dan tidak menimbulkan pemahaman yang berbeda antara ustadz/ah 
yang satu dengan yang lain. Selain itu juga sesi small group memberikan kesempatan untuk berdiskusi berbagai masalah sesuai tema kajian yang sedang dibahas.

5) Special Events

Special Events merupakan suatu kegiatan yang tidak selalu diadakan setiap saat, namun hanya pada waktu-waktu tertentu. Di SDIT BIAS Giwangan ada beberapa special events yang diadakan khusus untuk ustadz/ah ataupun siswa-siwinya. Special events tersebut diantaranya:

a) Kajero (Kajian Jelang Ramadhan) dan Pajero (Pawai Jelang Ramadhan). Dalam menyambut serta memeriahkan Bulan Ramadhan, Ustadz/ah SDIT BIAS Giwangan mengikuti kegiatan Kajero (Kajian Jelang Ramadhan) dan Pajero (Pawai Jelang Ramadhan) yang diselenggarakan langsung oleh Yayasan BIAS. Kegiatan ini diselenggarakan khusus diikuti oleh ustadz/ah BIAS dari berbagai jenjang. Selain untuk menyambut bulan suci Ramadhan, kegiatan tersebut ditujukan untuk memberi semangat kepada ustadz/ah dalam menjalani bulan yang penuh berkah itu.

b) Pokemon (Pondok Oke Ramadhan). Di bulan yang suci dan hanya sekali dalam setahun, SDIT BIAS Giwangan mengadakan Sanlat (Pesantren Kilat) khusus untuk siswa siswi kelas 3 sampai kelas 6. Kegiatan sanlat ini disebut juga dengan Pokemon (Pondok Oke Ramadhan). Dalam rangka mempererat tali kekeluargaan antara siswa dengan ustadz/ah dan karyawan, maka sanlat menjadi kegiatan yang paling tepat. Karena disaat kegiatan sanlat siswa siswi dan ustadz/ah mengikuti kegiatan yang menunjukkan kebersamaan seperti menginap di sekolah, berbuka puasa bersama, sholat tarawih berjamaah, makan sahur bersama, dan serangkaian kegiatan positif lainnya.

c) Posya (Pondok Syawal) 1435 H. Peristiwa spesial di bulan Syawal terjadi di Jaringan Sekolah BIAS Indonesia, tepatnya di Yogyakarta pada tanggal 7, 8 dan 9 Agustus yaitu PONSYA - Pondok Syawal 1435 H. Acara ini melibatkan 300 ustadz/ah dan karyawan maupun umi dari seluruh Jaringan Sekolah BIAS Indonesia. Misi penting dari acara ini adalah untuk memuliakan kembali profesi guru, suatu profesi yang sepertinya sedang terdegradasi dan tergerus oleh arus jaman. Oleh karena itu BIAS mengadakan acara semacam ini untuk menge" charge" rasa kebanggaan para ustadz/ah di Jaringan Sekolah BIAS Indonesia, agar terus tumbuh rasa bersyukur bahwa para ustadz/ah dan seluruh jajaran pendukung kegiatan pendidikan di BIAS berkiprah 
b. Kegiatan eksternal

di bidang yang begitu dimuliakan oleh Allah SWT dan Rasulullah SAW.41 Dari peristiwa tersebut dapat dilihat bahwa upaya dari yayasan dalam menciptakan hubungan yang erat antara ustadz/ahnya sangat jelas. Bukan hanya mempererat kedekatan antara ustadz/ahnya saja namun juga memberikan motivasi jiwa yang sebenarnya lebih dibutuhkan bagi ustadz/ahnya agar lebih mantapkan niat berjuang melalui pendidikan.

Kegiatan ini selalu berhungan atau ditujukan kepada publik atau masyarakat di luar warga sekolah, bisa dilakukan secara langsung, seperti rapat bersama, kunjugan tamu, dan lain-lain, konsultasi dengan tokoh-tokoh masyarakat. Atau tidak langsung, seperti; informasi lewat TV, radio, media cetak, pameran sekolah, dan lainlain. ${ }^{42}$ Adapun kegitan ekternal humas di SDIT BIAS Giwangan diantaranya:

1) Home visit

Home visit merupakan kegitan kunjungan ustadz/ah ke rumah siswa. Kegiatan ini biasanya dilaksanakan saat bulan ramadhan. Setiap ustadz/ah berkunjung kerumah setiap siswa dalam rangka menjalin kedekatan silaturahmi kepada wali siswa. Adapun hal yang diperbincangkan antara ustadz/ah dan wali siswa antara lain mengenai perkembangan siswa di sekolah, serta wawancara tentang anak baik menyangkut kepribadian ataupun kebiasaan sehari-hari di rumah. Dengan adanya saling memberikan informasi tentang anak tersebut, diharapkan dapat membantu dalam menangani permasalahan anak baik disekolah maupun dirumah. Selain itu juga sangat berpengaruh terhadap kepercayaan wali siswa, dengan home visit tersebut maka wali siswa akan semakin mantap menyekolahkan putra-putrinya di SDIT BIAS Giwangan karena merasa bahwa sekolah benar-benar memperhatikan hasil pendidikan yang inggin dicapai dengan peduli dengan perkembangan anak didiknya bukan hanya saat di sekolah saja melaikan saat siswa-siswinya di rumah juga.

2) Pertemuan dengan Orang Tua

a. Stadium General

Stadium General merupakan pertemuan khusus antara sekolah dengan wali siswa baru. Pertemuan ini diadakan guna memberikan informasi atau mengenalkan lebih jauh tentang SDIT BIAS Giwangan kepada wali siswa baru, terutama tentang sistem pengajarannya. Di mana hal ini dimaksudkan

\footnotetext{
${ }^{41}$ lpitbias.org/bias/ diakses pada 11 Agustus 2014

42 Suryosubroto, Manajemen Pendidikan di Sekolah (Jakarta: PT Asdi Mahasatya, 2004), 163.
} 
agar wali siswa mengerti dan memahami sistem yang digunakan di SDIT BIAS Giwangan.

b. Laporan Perkembangan

Laporan perkembangan maksudnya adalah pihak sekolah memebrikan laporan pada wali siswa tentang kemajuankemajuan, prestasi, dan kelemahan siswa pada orang tuanya. Laporan perkembangan ini dibuat 3 bulan sekali. Dengan laporan perkembangan maka wali siswa akan memperoleh penilaian terhadap hasil pekerjaan anaknya, juga terhadap pekerjaan guru di sekolah.

c. Musyawarah dengan Wali Siswa

Musyawarah bersama dengan wali siswa merupakan pertemuan pihak sekolah dengan wali siswa guna membahas berbagai keperluan yang berkaitan dengan kegiatan sekolah, siswa-siswi maupun keperluan yang lain. Tujuan dari musyawarah ini antara lain adalah membina kerja sama antara wali siswa dengan sekolah. Di SDIT BIAS Giwangan kegiatan musyawarah dengan wali siswa dilaksanakan ketika akan ada kegiatan yang membutuhkan koordinasi dengan wali siswa langsung. Misalnya, ketika sekolah memerlukan donatur dalam pembangunan mushola sekolah, maka akan ada rapat dengan wali siswa sehingga wali siswa pun dapat membantu mencari donaturya. Ketika akan ada kegiatan PKL siswa-siswi ke Jakarta, maka akan diadakan rapat dengan wali siswa guna membahas persiapan yang harus dilakukan.

d) Bakti Sosial

Dalam menyambut bulan suci Ramadhan, SDIT BIAS mengadakan Bakti sosial setiap tahunnya. Target dari baksos adalah masyarakat atau warga sekitar sekolah yang kurang mampu secara ekonomi. Kegiatan baksos selain ditujukan untuk membantu warga sekitar juga bertujuan untuk menjalin hubungan dengan warga sekitar sehingga keharmonisan lembaga sekolah dengan masyarakat tetap terjaga. Selain itu kegiatan baksos ini juga dijadikan ajang untuk mengajarkan sikap dermawan serta melatih kepedulian kepada siswa- siswi terhadap sesama terutama masyarakat yang kurang mampu. Adapun cara humas SDIT BIAS Giwangan dalam menyampaikan kegiatan baksos ini adalah dengan menghubungi kepala desa atau kepala dusun agar dapat mengkoordinasi masyarakat yang berhak mendapatkan baksos. Kemudian kepala desa atau kepala dusun menkoordinasi dan memberikan data kepada sekolah. Sehingga sasaran baksos tepat sasaran. Di samping acara baksos, biasanya diadakan pula Bazar atau pasar murah. Bazar ini biasanya menyedikan 
pakaian pantas pakai yang dismbangkan oleh siswa-siswi maupun wali siswa. Pakaian pantas pakai tersebut akan disediakan di bazar dengan harga miring sehingga dapat terjangkau oleh masyarakat yang kurang mampu. Dan yang lebih penting dari acara baksos ini adalah keterlibatan langsung orang tua siswa yaitu baik sebagai panitia maupun donatur. Dengan keterlibatan langsung orang tua siswa, maka semakin memberikan kesempatan yang lebih bagi orang tua untuk berpartisipasi dalam kegiatan sekolah dan mengetahui program-program sekolah salah satunya baksos tersebut. Selain itu baksos merupakan ajang untuk menunjukkan bahwa sekolah memiliki kepedulian terhadap masyarakat pada umumnya.

e) Pengajian Rutin Mingguan

SDIT BIAS Giwangan tidak hanya memperdulikan tentang pendidikan agama siswa siswinya,yang ditunjukkan dengan system pembelajaran habit forming (pembiasaan) dimana dalam mengajarkan tentang ilmu agama, seperti halnya kewajiban sebagai seorang muslim yaitu menjalankan sholat tepat waktu, mengawali setiap kegiatan dengan do'a, dan kegiatan-kegiatan lain yang menunjukkan sifat seorang muslim. SDIT BIAS Giwangan juga memperdulikan tentang pengetahuan dan pemahaman orang tua siswa tentang agama Islam. Hal ini diwujudkan dalam bentuk kerja sama orang tua dengan pihak sekolah yang selalu mengadakan kajian rutin seminggu sekali khusus bagi orang tua siswa yang ingin belajar lebih banyak tentang agama Islam. Biasanya kajian khusus orang tua siswa ini dilaksanakan setiap Senin pagi di STAIT Yogyakarta. Kajian ini dibimbing oleh Direktur Yayasan, namun juga kadang dibimbing oleh Ustadzah senior di SDIT BIAS Giwangan.

f) Pentas Seni

Pentas seni di SDIT BIAS Giwangan diadakan dibeberapa kesempatan. Biasanya pentas seni diadakan bersamaan dengan acara yang menghadirkan wali siswa atau masyarakat luar sekolah. Seperti saat ada acara baksos, ITC (International Trade Centre), PAT (Pesta Akhir Tahu), laporan perkembangan, pesta kembang api saat sanlat, dan diberbagai kesempatan lainya. Pentas seni ini didakan bukan hanya sekedar untuk hiburan tetapi terkandung makna yang lebih luas manfaatnya. Manfaat yang dirasakan bukan hanya untuk siswa-siswi yang melakukan pertunjukan saja tetapi juga ustadz/ah, warga sekolah lainnya, dan orang tua serta masyarakat luar sekolah lainnya. Bagi siswa-siswi yang melakukan pertunjukan, pentas 
seni bertujuan untuk melatih siswa-siswi untuk memberikan kesempatan siswa-siswinya untuk menunjukkan kebolehannya, untuk melatih anak mengembangkan potensinya, melatih anak mempunyai rasa tanggung jawab dan percaya diri yang tinggi. Sedangkan utuk ustadz/ahnya dapat memberikan rasa kebenggaan tersendiri sebagai pembimbing sekaligus guru dari siswa-siswi yang pentas. Begitu juga dengan orang tua yang dapat melihat lansung pentas putra-putrinya, maka akan semakin bangga dengan putra-putrinya sekaligus menciptakan rasa kepercayaan yang lebih tinggi terhadap sekolah karena langsung dapat menyaksikan hasil pendidikan dari polah tingkah putra-putrinya. Dengan begitu akan memunculkan citra yang bagus bagi SDIT BIAS Giwangan itu sendiri menjadi sekolah unggulan yang tidak lagi diragukan kualitas pendidikannya.

g) Pawai

Dalam memeriahkan hari-hari besar seperi bulan Ramadan, idul fitri, dan idul Adha SDIT BIAS Giwngan mengadakan pawai atau berkeliling baik secara sederhana maupun secara besar-besaran. Saat siswa-siswi mengikuti kegiatan sanlat atau Pondok Oke Ramadhan ada sesi pawai bersama dan pesta kembang api, dimana siwa-siswi berkeliling di daerah sekitar sekolah dan membawa berbagai lampion yang menarik, sehingga dapat dilihat langsung oleh masyarakat sekitar yang dilewati saat perjalanan pawai. Kemudian finis di lapangan untuk melaksanakan pesta kembang api. Di mana pesta kembang api ini juga mengahadirkan wali siswa yang ingin melihat langsung kegiatan anaknya saat sanlat. Demikian juga bagi warga sekitar yang rumahnya berdekatan dengan lokasi pesta kembang api, mereka dapat menyaksikan langsung kemeriahan pesta kembang api tersebut dan itu menjadi hiburan tersendiri bagi mereka. Hal ini menunjukkan bahwa kedekatan antara sekolah dengan wali siswa maupun sekolah sangat terbuka. Selain itu pesta kembang api juga mempunyai nilai edukatif tersendiri bagi siswa-siswi bahwa dengan adanya pesta kembang api ini siswa-siswi dapat mengenal berbagai macam kembang api, dan siswa siswi dapat menikamati berbagai keindahan kembang api tanpa pemborosan, yaitu mengeluarkan uang yang lebih hanya untuk membeli kembang api. Saat Hari Raya Idul Fitri maupun Idul Adha tiba SDIT BIAS Giwangan juga mengadakan pawai ke wilayah sekitar sekolah. Apabila saat sanlat pawai hanya dilaksanakan dengan berjalan kaki, maka saat Hari Raya ini pawai biasanya menggunakan dokar atau kendaraan tradisional lainnya serta 
jalur pawai pun lebih jauh. Selain itu pawai ini dilaksanakan saat siang hari, sehingga akan lebih banyak masyarakat yang dapat menyaksikan langsung kegiatan pawai ini.

h) Memanfaatkan Special Moment

a. KBM Khusus

Saat ada tanggal merah di kalender masehi, SDIT BIAS Giwangan tetap ada kegiatan KBM, tidak seperti sekolah pada umumnya. Karena sekolah pada umumnya akan libur saat tanggal merah. Namun SDIT BIAS Giwangan malah memanfaatkan libur tanggal merah tersebut untuk KBM yang sangat berbeda dari biasanya. KBM saat tanggal merah tersebut dinamakan KBM Khusus. KBM Khusus merupakan KBM yang secara Khusus disiapkan sekolah untuk memberi kesempatan bagi siswa-siswi belajar bersama orang tua. Jadi KBM tersebut yang memberikan materi adalah orang tua dari siswa. Adapun materi yang disampaikan sesuai dengan profesi atau keahlian yang dimiliki oleh wali siswa. Misalnya, Ibu dari siswa kelas 3 mempunyai keahlian membuat berbagai macam accecoris, maka pada kesempatan KBM Khusus, wali siswa tersebut diundang oleh sekolah untuk memberikan pelajaran kepada siswa-siswi kelas 3 membuat hiasan pintu. Salah satu wali siswa kelas 1 mempunyai profesi petani, maka siswa-siswi kelas 1 diajak belajar bercocok tanam, dll. Sesuai yang dijelaskan oleh ustadzah wali kelas 2A. "Orang tua di ajak berkicimpung dengan anak-anak. Ya nanti ngajar, bisa berbagi pengalaman, bisa belajar membuat ketrampilan, atau apalah. Missal orang tua dibidang pertanian, oh nanti diajak belajar bercocok tanam bareng, oh orang tuanya pinter masak, oh nanti masak sama anak-anak, orang tuanya pinter bikin accesorris, oh nanti bikin accesoris, itu dimasukin kedalam KBM. Itu namanya KBM Khusus". ${ }^{43}$

b. ITC (International Trade Centre)

Salah satu poin visi unggulan SDIT BIAS Giwangan adalah mencetak siswa yang mempunyai daya saing global. Oleh karena itu siswa-siswi dibekali pembelajaran yang mengajarkan interpreneur. Salah satu wujud dari program interpreneur tersebut adalah diadakannya ITC (International Trade Center) yaitu kegiatan melatih anak untuk memiliki jiwa bisnis yang tinggi melalui kegiatan berjualan. Sesuai dengan namanya Internasional Trade Center maka setiap stan atau kelompok menggunakan nama negara-negara

${ }^{43}$ Hasil wawancara dengan Ustadzah Kurnia,... 
besar di dunia, seperti Prancis, Singapura, Italia, Jerman, Inggris, Malaisya, dll. Nama kelompok menggunakan nama-nama negara besar di dunia dimaksudkan untuk memberi gambaran kepada siswa-siswi bahwa mereka sedang berlatih berbisnis tingkat dunia, yang nantinya akan memberi motivasi kepada mereka untuk menjadi seseorang yang dapat berkecimpung dalam dunia bisnis, bukan hanya di tingkat nasional namun hingga tingkat internasional. Dalam kegiatan ITC bukan hanya siswa-siswi saja yang ikut berpartisipasi, namun juga melibatkan ustadz/ah serta orang tua siswa. Siswa-siswi kelas 4 sampai 6 merupakan pelaku utama dalam kegiatan ITC tersebut, karena mereka yang dibentuk dalam kelompok-kelompok yang nantinya akan berjualan beraneka macam makanan, minuman, mainan, accecories, dll. Bukan hanya sekedar berjualan, namun mereka diajarkan bagaimana cara mempromosikan barang dagangannya agar laris, mengasah kreatifitas karena anak-anak diharuskan membuat sendiri selebaran atau brosur sesuai kreatifitas mereka untuk mempromosikan dagangannya. Sedangkan siswa kelas 1 sampai kelas 3 yang menjadi pembeli. Jadi mereka diajarkan untuk manajemen keuangan, karena setiap anak hanya boleh membawa uang sejumlah yang telah ditentukan oleh wali kelas mereka. Sehingga mereka tidak dapat membeli semua barang yang mereka inginkan, namun hanya terbatas sesuai uang yang dibawa. Selain manfaat atau nilai edukatif yang didapat oleh siswa, kegiatan ITC ini juga mempunyai banyak manfaat lain diantaranya, menambah kedekatan emosional antara ustadz/ah dengan siswa-siswanya, terutama ustadz/ah yang menjadi pendamping kelompok ITC. Secara langsung ustadz/ah dan siswa-siswi menjadi satu tim yang bergerak dalam mensuksekan kelompoknya masing-masing. Berbeda lagi dengan orang tua yang mengikuti acara ITC secara langsung. Mereka dengan semangat membantu putra-putrinya untuk menyiapkan barang dagangan yang akan dijajakan. Dengan begitu maka akan memberikan kedekatan yang lebih antara orang tua dan anak-anaknya, karena anak-anaknya merasa sangat didukung dan diperhatikan oleh orang tuanya terutama dalam hal pendidikan. Dari kegiatan ITC tersebut dapat dilihat bahwa kedekatan, kekompakan antara ustadz/ah, siswa-siswi dan bahkan orang tua sangatlah bagus. Dan hal ini yang akan memberikan dampak positif bagi keberhasilan pendidikan siswa-siswinya 
i) Penyebaran Informasi Sekolah melalui Media Masa Dalam menyebarkan informasi tentang sekolah, SDIT BIAS Giwangan menggunakan berbagai media seperti brosur, pamphlet, pemasangan spanduk, serta melaui media internet. Sehingga masyarakat luas terutama wali siswa lebih mudah mendapatkan informasi tentang sekolah, misalnya tentang profil sekolah, kegiatan-kegiatan sekolah, dll. Penyebaran informasi tersebut dikemas dengan rapi dan menarik, karena desain dan gaya penyampaian informasi tersebut sangat berpengaruh terhadap minat masyarakat pada sekolah. Sebagai mana yang dituturkan oleh Kepala sekolah SDIT BIAS Giwangan berikut ini: "oh ya, lewat internet, terus publikasi yang out door masang pampflet, baik umum atau khusus ditempel di masjid-masjid, terus pemasangan spanduk, brosur-brosur" 44

j) Sms getway

Penyebaran informasi tentang kegiatan disekolah dapat dikabarkan melalui surat pemberitahuan. Namun dapat juga disampaikan melalui sms getway, yaitu pemberitahuan informasi mengenai kegiatan sekolah melalui komunikasi via sms. Dengan sms get way informasi akan lebih akurat dan lebih cepat tersampaikan. Biasanya wali siswa SDIT BIAS Giwangan meminta langsung nomor handphone wali kelas untuk mencari informasi baik yang berhubungan dengan anak mereka, kegiatan disekolah ataupun informasi lainnya. Sesuai pernyataan wali siswa berikut ini, "Jadi memang saya masih mencari bentuk informasi yang pas. Kalau selama ini yang saya lakukan sejak dia zaman TK itu saya pegang nomer ustadzah wali kelas. Jadi lebih cepet dari pada menunggu surat dari sekolah, karena kadang-kadang saya lupa dan nggak buka tas, kalau sama ustadzahnya kan lebih cepet". ${ }^{45}$

k) Informasi mulut ke mulut

Promosi yang paling efektif untuk menarik kepercayaan wali siswa adalah dengan informasi mulut-kemulut. Sesuai dengan pernyataan salah satu wali siswa kelas 2A. "Tapi itu sudah otomastis dari orang tua ketika orang tua itu merasa puas dengan BIAS, dia akan gethok tular. Nah kebetulan karena besik saya psikolog, banyak temen-temen yang bertanya kepada saya SD

\footnotetext{
${ }^{44}$ Hasil wawancara dengan Bp. Nashoha Alasyar selaku kepala sekolah, pada Senin, 21 Juli 2014

45 Hasil wawancara dengan Ibu Uswatun Khasanah wali siswa kelas 2 pada Jum'at, 18 Juli 2014 40
} 
mana yang direkomendasikan. Ea githu ja" ${ }^{46}$ Orang tua yang merasa puas dengan layanan sekolah maka akan mempunyai tingkat kepercayaan yang tinggi. Sehingga mereka pun akan memberikan kesan yang positif terhadap masyarakat disekitarnya seperti kerabat, tetangga, teman kantor atau yang lainnya. Kesan yang positif tersebut sangat berpengaruh terhadap minat masyarakat untuk memasukkan putra-putrinya ke SDIT BIAS Giwangan, sesuai dengan yang dituturkan oleh kepala sekolah SDIT BIAS Giwangan. "Kepercayaan wali siswa di BIAS, sebenarnya cukup tinngi. Itu ditunjukkan dengan indikator siswa yang masuk dari berbagai jenjang itu kebanyakan hampir $50 \%$ masuk ke jenjang berikutnya. Terus penerimaan siswa baru itu lebih banyak dari informasi dari wali siswa, mulut ke mulut". ${ }^{47}$

1) Bekerja Sama dengan Instansi Lain

Sekolah sangat membutuhkan adanya kerjasama dengan lembaga-lembaga atau instansi-instansi lain, baik swasta maupun pemerintah, seperti hubungan sekolah dengan lembaga pedidikan yang sederajat atau bahkan yang lebih tinggi seperti universitas, perusahaan-perusahaan swasta, maupun perusahaan-perusaan negara yang berkaitan dengan pendidikan. Sebagai mana kerjasama yang dijalin oleh SDIT BIAS Giwangan dengan instansi-intansi yang bergerak dalam berbagai bidang. Dengan intansi pemenintah seperti Dinas Pendidikan, sekolah dapat mengakses perkembangan informasi tentang pendidikan atau bahkan dapat mengikuti kegiatan-kegiatan yang diselenggarakan oleh Dinas Pendidikan. Sedangkan kerjasama antara SDIT BIAS Giwangan dengan lembaga pendidikan yang jenjangnya lebih tinggi, yaitu dengan beberapa universitas ternama di Yogyakarta seperti UNY, UMY, UGM, dan UIN, diwujudkan dalam kegiatan PKL siswa-siswi SDIT BIAS Giwangan. Sebagai mana yang dituturkan oleh Kepala Sekolah SDIT BIAS Giwangan Bapak Nasoha Alasyar, "yang berhubungan dengan PKL itu. Misalnya Seperti kita ke UMY belajar tentang bahasa, kita ke UGM untuk belajar tentang tekhnologi, kita kepeternakan belajar tentang hasil peternakan, hasil pertanian, bidang pemerintahan dengan

46 Hasil wawancara dengan Ibu Amanda Murtiningtyas wali siswa kelas 2 pada Jum'at, 18 Juli 2014

${ }^{47}$ Hasil wawancara dengan Bp. Nashoha Alasyar selaku kepala sekolah, pada Senin, 21 Juli 2014 
pemerintah, kunjungan ke pemerintah ingin menggali struktur pemerintah" 48

m) Aktif Bermasyarakat dan Bersosial dengan Warga Sekitar Sekolah. Sekolah berada ditengah-tengah masyarakat, sehingga mengharuskan adanya komunikasi atau hubungan dengan masyarakat sekitar guna menjaga keharmonisan dan agar sekolah mendapat dukungan dari masyarakat itu sendiri. Bentuk dari hubungan dengan masyarakat ini dapat berupa ikut berpartisipasi dalam kegiatan masyarakat. Selain itu kepedulian sekolah terhadap masyarakat sekitar sangat bagus. Seperti halnya saat ada warga sekitar sekolah yang meninggal, maka dari pihak sekolah juga takziah, selain itu saat momen KBM Lebaran pihak sekolah yaitu siswa-siswi berkunjung ke rumahrumah warga sekitar sekolah. Dari penjelasan diatas sudah sangat tergambar dengan jelas bahwa kedekatan hubungan antara sekolah dengan masyarakat sanggat bagus.

2. Upaya Manajemen Humas dalam Meningkatkan Kepercayaan Wali Siswa

Dari sekian banyak kegiatan humas di SDIT BIAS Giwangan, beberapa kegiatan diantaranya cukup efektif meningkatkan kepercayaan wali siswa terhadap SDIT BIAS Giwangan. Untuk mendapatkan kepercayaan masyarakat yang tinggi, terlebih dahulu SDIT BIAS Giwangan memperkuat sistem internal, yaitu menciptakan hubungan yang baik berupa kesolidan antar warga dalam sekolah itu sendiri mulai dari karyawan hingga kepala sekolah.

Kesolidan antar warga internal akan memberikan dampak positif bagi pandangan masyarakat terutama wali siswa. Jadi iklim di sekolah akan sangat terlihat jelas dan dapat dibaca oleh wali siswa yang selalu datang menghantar dan menjemput putra-putrinya.Selain itu kekompakan dan kesatuan pandangan tentang sekolah sendiri juga sangat berpengaruh terhadap kepercayaan wali siswa.Misalnya, apabila pandangan tentang sekolah antar ustadz/ah dengan karyawan berbeda, pastinya informasi yang akan disampaikan pada wali siswa akan berbeda pula atau tidak akurat, jelas ketiakakuratan informasi akan menurunkan kepercayaan wali siswa. Oleh karena itu, SDIT BIAS Giwangan mengupayakan karyawan dan ustadz/ah bisa kompak dan seragam dalam informasi seputar sekolah, kompak dan seragam dalam visi, dalam misi, serta dalam satu tujuan dan erat dalam ikatan emosional.

\section{Ibid.}


Upaya yang dilakukan SDIT BIAS Giwangan dalam merekatkan staff karyawan dan ustadz/ahnya adalah dengan mengadakan kegiatankegiatan yang cukup menghibur seperti rekreasi bersama, dan kegiatankegiatan yang bersifat motivasi jiwa sepeti kajian atau pengajian rutin mingguan. Secara tidak langsung, kegiatan-kegiatan yang dilakukan tersebut dapat menambah kesolidan dan kekompakan antar ustadz/ah dan karyawan. Dengan demikian akan memunculkan citra positif terhadap sekolah yang nantinya akan meningkatkan kepercayaan wali siswa terhadap sekolah.

Pohon yang kuat, mempunyai akar yang kuat pula. Bangunan yang kokoh berarti ditopang dengan pondasi yang kuat. Begitu pula solidnya pihak internal di SDIT BIAS Giwangan akan menjadi modal yang kokoh untuk melakukan kegiatan-kegiatan yang diadakan oleh sekolah, bahkan dapat melaksanakan program-program yang dapat meningkatkan kualitas sekolah terutama yang berhubungan dengan kehumasan.

Setelah hubungan pihak internal sekolah menjadi solid, maka upaya selanjutnya yang dilakukan adalah mempublikasikan humas ke pihak eksternal sekolah melalui berbagai kegiatan yang melibatkan masyarakat atau pihak eksternal baik langsung maupun tidak langsung seperti kegiatan home visit yaitu kegiatan berkunjung kerumah siswa untuk menjalin kedekatan langsung dengan orang tua guna membahas permasalahan-permasalahan secara lebih mendalam dan mencari solusi yang tepat bersama-sama. Selain itu, kegitan tersebut mendapat respon yang positif dari wali siswa sehingga tercipta suasana keakraban dalam kekeluargaan yang menumbuhkan rasa nyaman dan kepercayaan yang semakin meningkat. Karena sekolah sangat memperhatikan pendidikan siswa-siswinya bukan hanya saat disekolah namun juga saat dirumah

Hal lain yang sangat efektif untuk meningkatkan kepercayaan wali siswa terhadap sekolah bukan hanya kedatangan pihak sekolah ke rumah siswa, melainkan juga kegiatan yang mendatangkan wali siswa ke sekolah. Bahkan bukan hanya sekedar mendatangkan, melainkan juga lebih memberi kesempatan bagi wali siswa untuk lebih berpartisipasi kedalam kegiatan yang diadakan sekolah. Seperti halnya saat ada kegiatan baksos, yaitu bentuk kegiatan yang menunjukkan kepedulian sekolah terhadap masyarakat sekitar sekolah yang kurang mampu, orang tua menjadi panitia kegiatan tersebut. Begitu pula saat sekolah mengadakan kegiatan khusus seperti ITC (Internasional Trade Center), orang tua dapat berpartisipasi langsung untuk membantu keperluan yang dibutuhkan putra-putrinya, bahkan orang tua pun dapat berpartisipasi langsung dalam kegiatan belajar mengajar seperti saat tanggal merah. Orang tua diundang untuk mengajar pelajaran di kelas sesuai dengan profesi atau keahlian masing-masing. Kegiatan menghadirkan orang tua tersebut adalah KBM Khusus. 
Di samping kegiatan berkunjung ke rumah siswa dan mengundang wali siswa dalam bebagai kegiatan sekolah, kegiatan humas yang dapat meningkatkan kepercayaan wali siswa adalah memberikan pelayanan informasi yang akaurat dan cepat seperti penyebaran informasi melalui sms getway, memberikan kesempatan bagi wali siswa untuk bertanya bebas tentang keluhan baik yang menyangkut perkembangan anak atau informasi kegiatan sekolah secara langsung saat mengantar dan menjemput putra-putrinya. Selain itu juga penyebaran informasi melalui media masa seperti pamphlet, penyebaran brosur serta informasi melalui media internet sehingga lebih memmudahkan masyarakat mendapatkan informasi tentang sekalah.

3. Problematika Pelaksanaan Manajemen Humas di SDIT BIAS Giwangan

Dalam lembaga apapun tidak dapat lepas dari permasalahan, begitu pula pada lembaga-lembaga pendidikan. Dalam lembaga pendidikan di SDIT BIAS Giwangan ini juga memiliki berbagai permasalahan yang dialami oleh manajeman humas, permasalahann tersebut diantaranya adalah:

a. Minimnya Personalia yang Khusus Mengelola Kegiatan Manajemen Humas. SDIT BIAS Giwangan belum mempunyai tim khusus yang mengurus manajemen humas dalam stuktur organisasinya, sehingga manajemen humas secara keseluruhan masih dikelola langsung oleh kepala sekolah. Mengingat tanggung jawab bagian humas sangat banyak, sering kali berbagai kegiatan yang berhubungan dengan manajemen humas belum terlaksana secara optimal. Hal ini dipengaruhi juga dengan posisi lain sebagai humas yaitu kepala sekolah yang mempunyai tanggung jawab yang lebih banyak. Sehingga humas merasa kesulitan dalam menjalankan semua misi humas dalam kegiatan sekolah baik yang melibatkan interaksi langsung, baik internal sekolah sendiri maupun interaksi eksternal ke luar sekolah.

b. Pengelolan Manajemen Humas di Dalam Sekolah Masih Belum Maksimal. Pengelolaan manajemen humas di SDIT BIAS Giwangan belum tertata dengan rapi, bahkan belum terbentuk manajemen yang sesuai standar manajemen humas sekolah. Sebagaimana manajemen humas pada umumnya yang sudah merancang visi dan misi yang pasti, serta program-program kehumasan yang akan dilaksanakan. Selama ini kegiatan-kegiatan yang sebenarnya merupakan kegiatan humas terlaksana tanpa adanya kesadaran dan pemahaman terhadap kehumasan. Seperti halnya kegiatan-kegiatan sekolah yang berhubungan dengan masyarakat luar atau wali siswa tidak dipahami sebagai kegiatan humas, namun hanya dipahami sebagai kegiatan atau program sekolah yang harus dilakukan demi kepentingan pembelajaran atau kesuksesan acara tersebut. Beberapa guru dan karyawan yang terlibat dalam berbagai kegiatan dan program sekolah 
juga sering menguasai materi kehumasan, serta kurang mampu bersikap sebagai media penyambung komunikasi sekolah, sehingga unsur kehumasan yang seharusnya ada menjadi tidak tersampaikan dengan baik.

c. Kurangnya pemahaman masyarakat ekternal tentang bagaimana seharusnya pengelolaan hubungan masyarakat dibangun. Tingkat pendidikan masyarakat yang rendah, akan mempengaruhi pola pikir dalam melihat berbagai hal atau fenomena yang terjadi di sektitarnya. Bahkan cenderung akan memandang tabu apa yang tidak menjadi kebiasaan disekitar lingkungannya. Hal inilah yang menjadi salah satu hambatan bagi humas di SDIT BIAS Giwangan. Warga sekitar sekolah yang kurang paham dengan pendidikan, menganggap bahwa sekolah yang ada disekitar lingkungannya merupakan wadah untuk berbisnis. Misalnya saat warga masyarakat akan mengadakan kegiatan, masyarakat akan meminta sumbangan dana sesuai yang mereka inginkan kepada pihak sekolah. Selain itu, masyarakat mempunyai pandangan bahwa kegiatan atau sistem pembelajaran yang ada di SDIT BIAS Giwangan bukanlah sistem pendidikan yang seharusnya diajarkan kepada anak-anak. Misalnya, SDIT BIAS Giwangan menerapkan sistem pembelajaran learning by doing yaitu anak-anak belajar, dalam memahami ilmu yang diajarkan dengan langsung mempraktikkannya. Namun masyarakat yang tidak paham, maka menganggap bahwa pembelajran menggunakan sistem learning by doing tersebut anak-anak hanya diajari bermain saja, tanpa ada nilai edukatifnya. Sehingga yang seharusnya masyarakat memberikan dukungan terhadap pendidikan yang ada, justru timbul kesalah pahaman yang menyebabkan hubungan antar sekolah dengan warga masyarakat menjadi kurang harmonis.

4. Solusi Problem Pelaksanaan Manajemen Humas di SDIT BIAS Giwangan Yogyakarta

a. Menjalankan Misi Kehumasan dengan Melibatkan Seluruh Guru dan Karyawan. Kegiatan humas yang banyak, membutuhkan orang yang banyak pula dalam menjalankannya. Untuk itu dalam melaksanakan kegiatan-kegiatan humas baik kegiatan internal maupun ekternal melibatkan seluruh ustadz/ah dan karyawan untuk membantu, sehingga kegiatan-kegiatan humas tersebut dapat berjalan lebih efektif dan efisien. Jadi dalam pelaksanaan kegiatan humas lebih baik mengikutsertakan para karyawan atau ustadz/ah. Misalnya,

b. Sosialisasi Pengetahuan tentang Humas terhadap Para Ustadz/ah dan Karyawan agar Menjadi Penyambung Komunikasi Kepada Wali Siswa. Orang yang kurang paham dengan kehumasan, maka dia kurang mampu berperan baik sebagai humas untuk menyambung hubungan yang komunikatif, begitu pula dengan ustadz/ah serta karyawan di SDIT BIAS Giwangan yang kurang paham dengan 
humas. Oleh karena itu, perlu adanya sosialisasi kepada ustadz/ah serta karyawan tentang humas, sehingga sedikit demi sedikit kesadaran bahwa mereka mempunyai peran penting bagi aktivitas humas terutama dalam menjaga hubungan baik dengan masyarakat luar atau wali siswa dan membangun citra sekolah akan tumbuh. Adapaun cara mensosialisasikan humas kepada ustadz/ah atau karyawan adalah dengan mengadakan talk show atau dialog interaktif tentang humas dengan mendatangkan nara sumber yang berkompeten dibidang kehumasan. Ataupun mengadakan pelatihan humas dengan memberikan tanggung jawab kepada ustadz/ah atau karyawan untuk mengurus atau menangani salah satu kegiatan yang berkaitan dengan humas.

c. Meningkatkan Keaktifan Bermasyarakat dan Bersosial dengan Warga Sekitar. Hubungan antara sekolah dengan warga sekitar sekolah perlu ditingkatkan kembali. Interaksi antara pihak sekolah dan warga masyarakat yang intensif akan memberikan manfaat bagi kedua belah pihak. Sekolah akan lebih mengenal masyarakat dan dapat melihat kondisi keseluruhan masyarakat begitu pula dengan masyarakat, akan lebih mengenal sekolah sehingga tidak akan menimbulkan kesalahpahaman terutama dengan system pendidikan yang diterapkan sekolah. Dengan demikian maka akan saling mengerti tentang kebutuhan masing-masing dan akahirnya dapat mendukung satu sama lain. Adapun cara untuk berinteraksi dengan warga masyarakat sekitar agar komunikasi terbagun secara intens yaitu mengadakan kegiatan rutin dengan warga sekitar, ataupun menggunakan hari-hari spesial. Misalnya setiap 3 bulan sekali bersama-sama mengadakan kerja bakti lingkungan, atau saat Harihari besar seperti saat Hari Kemerdekan Indonesia mengadakan lomba yang mengikut sertakan warga sekolah maupun warga masyarakat pada umumnya.

\section{Kesimpulan}

Berdasarkan hasil penelitian yang dilakukan peneliti tentang Kontribusi Manajemen Humas dalam Meningkatkan Kepercayaan Wali Siswa Terhadap SDIT BIAS Giwangan, maka penulis dapat mengambil beberapa kesimpulan sebagai berikut:

1. Bentuk-bentuk kegiatan humas yang dilakukan SDIT BIAS Giwangan cukup efektif dalam membangun hubungan yang harmonis baik ke pihak internal maupun eksternal.

2. Upaya humas dalam meningkatkan kepercayaan wali siswa terhadap sekolah dilakukan dengan langkah awal memperkuat hubungan internal sekolah terlebih dahulu, kemudian membuka kesmpatan untuk wali siwa terlibat langsung dalam berbagai kegiatan sekolah, sehingga wali siswa lebih mantap dan yakin terhadap sekolah karena dapat melihat 
langsung atau mendapat gambaran nyata tentang berbagai program dan misi dari sekolah.

3. Dalam pelaksanaan humas, SDIT BIAS Giwangan mengalami berbagai kendala, baik kendala yang ada disebabkan oleh faktor internal maupun faktor eksternal.

\section{Daftar Pustaka}

Amalina, Sholihatin. Manajemen Humas dalam Membangun Kepercayaan Wali Siswa di SMP Islam Terpadu Bina Umat Sleman, Yogyakarta, Yogyakarta: Perpustakaan Universitas Islam Negeri Sunan Kalijaga (UIN) Yogyakarta, 2013.

Dwi Prasetyo, Danang. Pengelolaan Sekolah Islam Terpadu dalam Prespektif Administrasi Pendidikan. Hand Out Administrasi Supervisi Pendidikan STAIT. 2011.

Kepmendiknas No. 044/U/2002 Tentang Dewan Pendidikan dan Komite Sekolah

Mulyono, MA. Manajemen Administrasi dan Organisasi Pendidikan .Yogyakarta: Ar-Ruzz Media, 2008.

Muslimin. Hubungan Masyarakat dan Konsep Kepribadian. Malang: UMM Press. 2004.

Nasional, Depatemen Pendidikan. Kamus Besar Bahasa Indonesia Pusat Bahasa. Jakarta: PT. Gramedia Pustaka Utama, Edisi keempat. 2008

Nasution, Zulkarnain. Manajemen Humas di Lembaga Pendidikan. Malang: UMM Press, 2010.

Purwanto, Ngalim. Administrasi dan Supervisi Pendidikan. Bandung: PT. RemajaRosda Karya, 1993.

Pariyatun, Tri. Peran Hubungan Masyarakat (humas) dalam Pemasaran Jasa Pendidikan di SMA Terpadu Insan Cendikia Yogyakarta. Yogyakarta: Perpustakaan Universitas Islam Negeri Sunan Kalijaga (UIN) Yogyakarta, 2013

Qomar, Mujamil. Manajemen Pendidikan Islam. Jakarta: Penerbit Erlangga, 2007.

Riyanto, Yatim . Metodologi Penelitian Pendidikan. Surabaya: PENERBIT SIC, Cetakan ke 3. 2010

Sugiyono. Metode Pendidikan Pendekatan Kuantitaif, Kualitatif, dan RED. Bandung: Penerbit Alfa Beta. 2013

S. Margono. Metodologi Penelitian Pendidikan. Jakarta: Rineka Cipta. 2004. Cet.4.

Suryosubroto, Manajemen Pendidikan di Sekolah. Jakarta: PT Asdi Mahasatya, 2004.

UU RI No. 20 Tahun 2003 Tentang Pendidikan Nasional lpitbias.org 